\title{
Nonlinear optical response of the nematic liquid crystal doped with polymer-azo-dye complex under picosecond laser pulses excitation
}

\author{
A.V.Uklein ${ }^{1}$, E.V.Ouskova ${ }^{2,3}$, V.Ya.Gayvoronsky ${ }^{1}$ \\ ${ }^{1}$ Institute of Physics, National Academy of Sciences of Ukraine, \\ 46 Prospect Nauki, 03680 Kyiv, Ukraine \\ ${ }^{2}$ Beam Engineering for Advanced Measurements Co., \\ 809 South Orlando Ave., Suite I, Winter Park, 32789 FL, USA \\ ${ }^{3}$ Department of Applied Physics, Aalto University School of Science, \\ P.O.Box 13500 FI-00076 AALTO, Espoo, Finland
}

Received December 19, 2014

The nonlinear optical (NLO) response of the heterosystem based on nematic liquid crystal (LC) with incorporated polymer-azo-dye complex (PADC) was studied within the self-action of picosecond laser pulses at $532 \mathrm{~nm}$. It was shown the enhancement of the refractive NLO response efficiency up to $20 \%$ at lower excitation level $\left(0.5-20 \mathrm{MW} / \mathrm{cm}^{2}\right)$ and up to 5 times at higher excitation level $\left(20-600 \mathrm{MW} / \mathrm{cm}^{2}\right)$ for the PADC doped LC versus the components response and conventional azo-dye doped LC. The manifestation of three photoinduced mechanisms was observed with the rise of the PADC concentration in LC matrix: 1) orientation of the PADC; 2) trans-cis-trans isomerization; 3) cooperative response/aggregation effect. Each mechanism defines the heterosystem NLO response at corresponding PADC concentration range. The proposed smart material is promising for photonic application due to NLO properties control with variation of the PADC concentration.

Keywords: nonlinear optical response, photoinduced refractive index variation, polymerazo-dye complex, nematic liquid crystal, trans-cis isomerization, cooperative response, aggregation effect, orientation of polymer-azo-dye complex

Исследован нелинейно-оптический (НЛО) отклик гетеросистемы на основе нематического жидкого кристалла (ЖК) с инкорпорированным комплексом полимер-азокраситель (ПАКК) при самовоздействии пикосекундных лазерных импульсов с длиной волны 532 нм. Показано усиление рефрактивного НЛО отклика до $20 \%$ при меньшем $(0.5-$

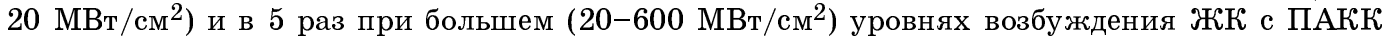
по сравнению с откликом компонент и системы ЗКК с азокрасителем. Выявлено проявление трех механизмов при увеличении концентрации ПАКК в ЖК: 1) ориентация ПАКК; 2) транс-цис-транс изомеризация азокрасителя; 3) кооперативный отклик/ әффект агрегации. Каждый механизм обусловливает НЛО отклик системы на соответствующем диапазоне концентраций. Предложенный "умный" материал является перспективным для применения в области фотоники за счет возможности управления его НЛО откликом путем подбора концентрации ПАКК.

Нелінійно-оптичний відгук нематичного рідкого кристала 3 інкорпорованим полімер-азобарвниковим комплексом при збудженні пікосеундними лазерними імпульсами. А.В.Уклеін, О.В.Уськова, В.Я.Гайворонський.

Досліджено нелінійно-оптичний (НЛО) відгук гетеросистеми на основі нематичного 
рідкого кристала (PК) з інкорпорованим полімер-азобарвниковим комплексом (ПАБК) при самовпливі пікосекундних лазерних імпульсів з довжиною хвилі 532 нм. Показано підсилення рефрактивного НЛО відгуку до $20 \%$ при меншому (0.5-20 $\left.\mathrm{MBT}^{\circ} \mathrm{cm}^{2}\right)$ та до 5 разів при більшому (20-600 МВт/см²) рівнях збудження РК з ПАБК у порівнянні з відгуком компонент та системи РК з азобарвником. Виявлено прояв трьох механізмів при збільшенні концентрації ПАБК у РК: 1) орієнтація ПАБК; 2) транс-цис-транс ізомеризація азобарвника; 3) кооперативний відгук/ефект агрегації. Кожен механізм обумовлює НЛО відгук системи на відповідному діапазоні концентрацій. Запропонований "розумний" матеріал $€$ перспективним для застосування у галузі фотоніки за рахунок можливості управління його НЛО відгуком шляхом підбору концентрації ПАБК.

\section{Introduction}

The heterogeneous systems based on the LCs are of a great interest due to their NLO response control ability with small amount of organic and inorganic dopants [1-4]. One of the most promising trends is the incorporation of azo-compounds. In this case, the NLO response enhancement can be observed due to LC order parameter modulation [5-7] or dye molecules reorientation, being determined by the photoinduced trans-cis transformation of the AD. Furthermore, the improved NLO properties of the heterosystems with incorporated comb-shape polymers and dendrimers was shown in [8-10].

Recently the promising results were obtained for the new self-orienting heterosystem based on the nematic LC with H-bonded polymer-azo-dye complex (PADC) [6]. It was shown the $\mathrm{AD}$ bounding to the polymer backbone leads to more efficient LCs' refractive NLO response enhancement versus the unbound $\mathrm{AD}$. The excitation was provided by the CW laser at $532 \mathrm{~nm}$.

In this work we present the studies of the PADC doped LC within the self-action of picosecond range laser pulses at $532 \mathrm{~nm}$. The excitation wavelength is at the tail of absorption band of the suspension and still can induce the photoisomerization reaction in the $\mathrm{AD}$. In order to obtain the detailed information about the photoinduced NLO mechanisms in heterosystem its components solutions were studied separately. Furthermore, we provide the analysis of the refractive NLO response of the LC doped with wide range of PADC concentration. The obtained results indicate the proper control of the heterosystem NLO properties by the PADC concentration selection.

\section{Studied objects and methodology}

In this work for the cells preparation the nematic liquid crystal 5CB (PI Chemicals Co., Ltd) with hydrogen-bonded polymer-azo-dye complex $\mathrm{P} 4 \mathrm{VP}(\mathrm{CHAB})_{0.5}$ were used. The polymer-azo-dye complex, PADC, was prepared from the polymer poly-4-vynil-pyridine P4VP (Mn: $1000 \mathrm{~g} / \mathrm{mol}$, Mw: $1200 \mathrm{~g} / \mathrm{mol}$; Polymer Source Inc.) and the azo-dye 4-cyano4'-hydroxyazobenzene - CHAB (BEAM Co.) by mixing solutions of polymer and $\mathrm{AD}$ in dimethyl formamide (DMF) at certain concentration to get 0.5 complexation rate (the procedure of complex preparation is fully described in [4]) that is the number of AD molecules is twice less than the number of side fragments of the polymer. Complex solution then was added into LC and DMF was completely evaporated at room temperature during few days. The concentration of PADC in LC was 1 wt.\%. For the determination of the $\mathrm{AD}$-polymer bonding impact the conventional LC with unbound $\mathrm{AD}$ $(0.5$ wt. $\%)$ was prepared. In order to determine the components contribution into the NLO response of the heterosystem the components solutions in DMF were also studied. The concentration of the compounds in solution was 0.5 wt. $\%$ for the polymer P4VP and $\mathrm{CHAB}$ and 1 wt. $\%$ for the PADC.

The sandwich-type cells were filled with the suspensions, dye-doped LC and pure LC at the temperature above LC clearing point $\left(50^{\circ} \mathrm{C}\right)$ and slowly cooled down to the room temperature. Thicknesses of the cells were set to about $50 \mu \mathrm{m}$. According to [4], the presence of $\mathrm{P} 4 \mathrm{VP}(\mathrm{CHAB})_{0.5}$ in suspension leads to the self-orientation and provides the homeotropic alignment of $\mathrm{LC}$, and so the cells for complex-doped LCs were made of very clean glasses without any covering. Whereas the inner surfaces of the reference cell with 5CB and 5CB cells with azo-dye were covered with polyimide films of SE-1211 to provide good homeotropic alignment. The alignment of LC's cells was checked with polarizing microscope.

The optical absorption spectra of the $\mathrm{AD} / \mathrm{PADC}$ solutions in DMF versus the LC doped with the same AD/PADC concentration recorded by Shimadzu UV-2450 are presented in Fig. 1. It can be seen that there is no absorption for the DMF (I), polymer (II) and pure LC (V) in the studied wavelength range. The azo-dye in solution 


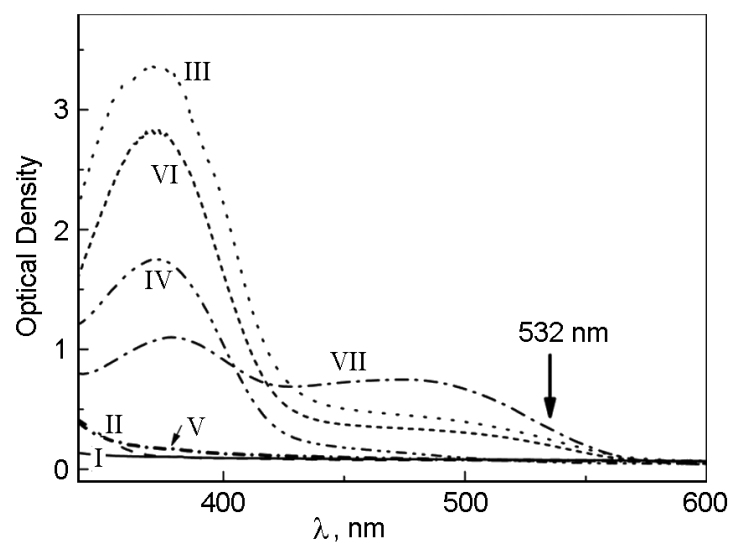

Fig. 1. The absorption spectra of the studied solutions and LC cells: I - DMF, II 0.5 wt. $\%$ solution of the polymer P4VP in $\mathrm{DMF}$, I II -0.5 wt. $\%$ solution of the $\mathrm{AD}$ in $\mathrm{DMF}, \mathrm{IV}-0.5$ wt. $\%$ of $\mathrm{AD}$ in $\mathrm{LC}$ matrix, $\mathrm{V}$ - pure LC matrix, VI -1 wt. $\%$ solution of PADC in DMF, VII - 1 wt. $\%$ of PADC in LC matrix.

(III) demonstrates main absorption maximum at $373 \mathrm{~nm}$ which also was observed in PADC solution (IV). The PADC-doped LC (VII) demonstrates the enhanced absorption at $470 \mathrm{~nm}$ versus the $\mathrm{AD}$ and PADC solutions in DMF.

The excitation quantum energy $2.33 \mathrm{eV}$ (532 $\mathrm{nm}$ ) is in the $\mathrm{AD} / \mathrm{PADC}$ absorption band and consequently is appropriate for the study of the photoinduced processes in the nanocomposites.

The NLO response due to the self-action of the picosecond laser pulses (repetition rate $10 \mathrm{~Hz}$ ) in the cells was studied within the laser beam spatial profile analysis in the far field [11]. The experiments were provided for two different sample positions $G_{1}$ and $G_{2}$ after the focusing lens $L(f=11 \mathrm{~cm})$ with the laser beam spot diameters about $0.95 \mathrm{~mm}$ (at $14 \mathrm{~cm}$ distance from focus) and $0.22 \mathrm{~mm}$ (at $3 \mathrm{~cm}$ distance from focus). The low excitation level $G_{1}$ corresponds to the peak laser intensity range $0.5-20 \mathrm{MW} / \mathrm{cm}^{2}$ whereas high excitation level $G_{2}$ to the range $20-600 \mathrm{MW} / \mathrm{cm}^{2}$. The larger beam aperture (position $G_{1}$ ) provided more efficient spatial averaging of material response and hence more efficient suppression of inhomogeneities impact.

The proposed method was successfully applied for the LC based heterogeneous systems studies [6, 12]. The detailed models for the real and imaginary parts of the cubic NLO susceptibility calculation from the experimental data are given in $[13,14]$. The real/(imaginary) part characterizes the photoinduced variations of the refractive index $\Delta n \sim$
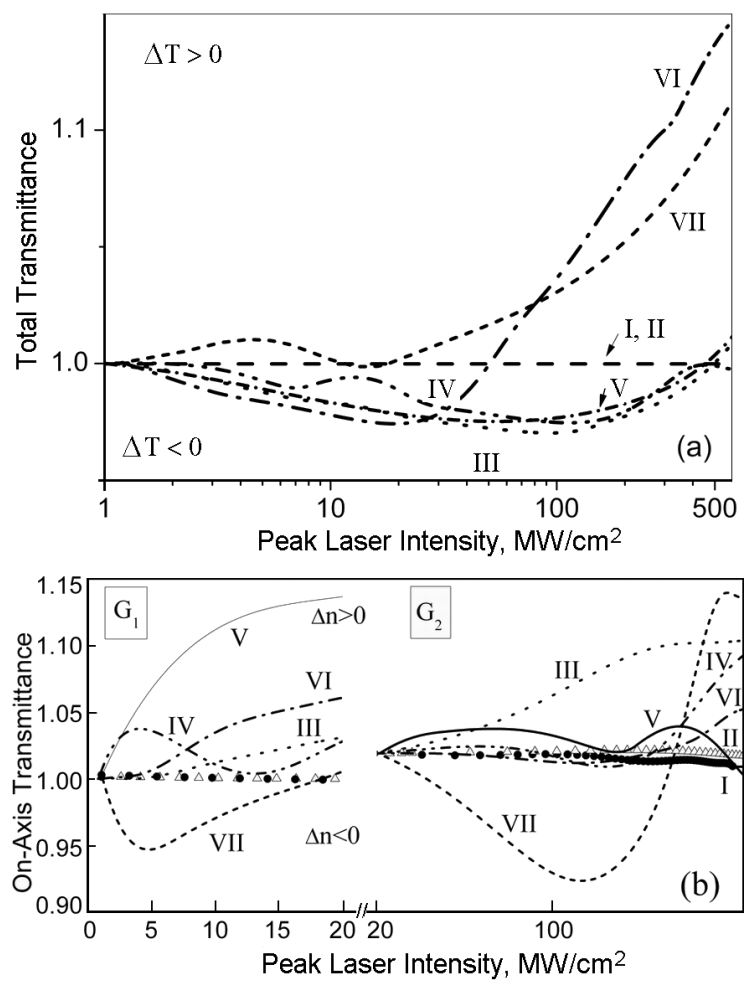

Fig. 2. The NLO responses due to the self-action of the picosecond laser pulses at $532 \mathrm{~nm}$ : (a) - the total transmittance dependences normalized on spectral transmittance of the studied cells (the dependences are presented in logarithmic scale); (b) - the photoinduced variations of the on-axis transmittance for two studied geometries $G_{1}$ and $G_{2}$ (the dependences for $G_{2}$ are presented in logarithmic scale). I - DMF, II -0.5 wt. $\%$ solution of the polymer P4VP in DMF, III - 0.5 wt. $\%$ solution of the $\mathrm{AD}$ in $\mathrm{DMF}, \mathrm{IV}-0.5 \mathrm{wt} \%$ of $\mathrm{AD}$ in LC matrix, $\mathrm{V}$ - pure LC matrix, VI -1 wt. $\%$ solution of PADC in DMF, VII 1 wt. $\%$ of PADC in LC matrix.

$\operatorname{Re}\left(\chi^{(3)}\right) I /($ the absorption coefficient $\Delta \alpha \sim$ $\left.\operatorname{Im}\left(\chi^{(3)}\right) I\right)$ within the peak laser intensity $I$.

\section{Experimental results}

1. The NLO response of the PADC doped $L C$ heterosystem versus the components response

The photoinduced total transmittance dependences versus the peak laser intensity of the studied solutions are presented in the Fig. 2a. The dependences are plotted in semi logarithmic scale. The relative error is about $\pm 0.7 \%$. In order to clarify photoinduced contribution into the total transmittance variation we normalized the each experimental dependence shown in the insert on the corresponding spectral transmittance 
at $532 \mathrm{~nm}$. It can be seen that the reference photoinduced absorptive variations of DMF and P4VP in studied peak laser intensity range is rather small and within the experimental error.

The pure LC matrix (curve V) demonstrates the photoinduced darkening about $2.5 \%$ that saturates at peak laser intensity $\sim 30 \mathrm{MW} / \mathrm{cm}^{2}$ and turns to differential photobleaching.

The AD in DMF (curve III) demonstrates the $\sim 3 \%$ of photoinduced darkening with the saturation at about $100 \mathrm{MW} / \mathrm{cm}^{2}$ that also turns to differential photobleaching. The absorptive NLO response of the $\mathrm{AD}$ in LC matrix (curve IV) is close to the one in DMF. The difference observed in the peak laser intensity range $5-30 \mathrm{MW} / \mathrm{cm}^{2}$ can be attributed to the mutual influence of the subsystems: dye and LC.

The bounding of the AD molecules to the polymer leads to the enhancement of the photodarkening efficiency of the solution at up to 2 times peak laser intensity range $I<3 \mathrm{MW} / \mathrm{cm}^{2}$ (curve VI). In comparison to the absorptive NLO response of the unbound $\mathrm{AD}$, the saturation of the process occurs at much less peak laser intensity $\sim 30 \mathrm{MW} / \mathrm{cm}^{2}$. At higher intensities the PADC solution in DMF also shows enhancement of the efficiency (up to $90 \%$ ) of the photobleaching phenomenon compared to the $\mathrm{AD}$ solution.

The absorptive NLO response of the PADC doped LC cell (curve VII) significantly differs from the one in DMF solution and can not be presented as the sum of the components responses. The photoinduced bleaching observed at peak laser intensities $I<5 \mathrm{MW} / \mathrm{cm}^{2}$ is followed by the differential photodarkening process in the range $5<I<10.5 \mathrm{MW} / \mathrm{cm}^{2}$. At higher intensities the absorptive NLO response of the PADC in LC matrix is similar to the one in DMF solution.

The photoinduced on-axis transmittance dependences were normalized on the total one to avoid the impact of the photoinduced absorptive NLO response on the refractive one. The obtained results versus the peak laser intensity are presented in Fig. 2b. It can be seen that the reference components $\mathrm{DMF}$ and P4VP demonstrate the slight selfdefocusing $(<1 \%)$ which is in the error range. The pure LC matrix demonstrates the monotonic self-focusing effect up to $12.5 \%$ for the lower excitation level $G_{1}$. For the geometry $G_{2}$ the sign inversion to

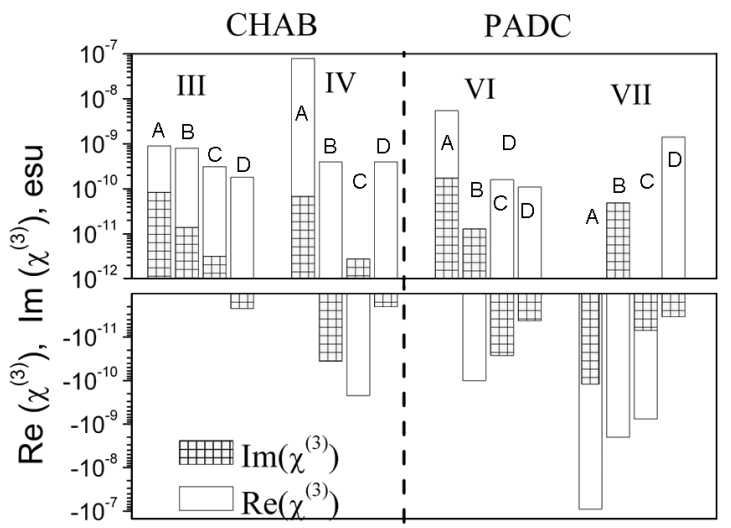

Fig. 3. The imaginary and real parts of the cubic NLO susceptibility $\chi^{(3)}$ calculated for chosen peak laser intensity ranges A: $I<3 \mathrm{MW} / \mathrm{cm}^{2}$, B: $20<I<50 \mathrm{MW} / \mathrm{cm}^{2}$, C: $50<I<200 \mathrm{MW} / \mathrm{cm}^{2}$ and D: $300<I<$ $500 \mathrm{MW} / \mathrm{cm}^{2}$ ranges. Transparent bars correspond to the $\operatorname{Re}\left(\chi^{(3)}\right)$ magnitudes, patterned - to the $\operatorname{Im}\left(\chi^{(3)}\right)$ correspondingly.

differential self-defocusing was observed at about $\sim 40 \mathrm{MW} / \mathrm{cm}^{2}$ for pure LC (curve V).

For the $\mathrm{AD}$ solution the monotonic photoinduced self-focusing effect up to $7 \%$ was observed for both excitation levels. In the LC matrix the AD refractive NLO response is not monotonic for both excitation levels. The sign inversion was observed at about $\sim 4 \mathrm{MW} / \mathrm{cm}^{2}$ and $14 \mathrm{MW} / \mathrm{cm}^{2}$ for the geometry $G_{1}$, and at about $50 \mathrm{MW} / \mathrm{cm}^{2}$ and $170 \mathrm{MW} / \mathrm{cm}^{2}$ for the geometry $G_{2}$. Thus, the LC matrix significantly impacts the refractive NLO response of the azo-dye.

The bounding of the azo-dye to the polymer similarly leads to the considerable change of its refractive NLO response efficiency (curve VI). At lower excitation level $G_{1}$ the enhancement of the self-focusing effect was observed. Opposite, for the higher excitation level $G_{2}$ the reduction of the refractive NLO response efficiency was shown.

The most efficient photoinduced on-axis transmittance variations were observed for the PADC doped LC. For both excitation levels the heterosystem demonstrate the nonmonotonic refractive NLO response: the self-defocusing turns to self-focusing at about $5 \mathrm{MW} / \mathrm{cm}^{2}$ (in geometry $G_{1}$ ) and $130 \mathrm{MW} / \mathrm{cm}^{2}$ (in geometry $G_{2}$ ). It can be seen that the refractive NLO response of the PADC doped LC can not be presented as the sum of the components responses.

The obtained magnitudes of the imaginary and real parts of the cubic NLO susceptibility $\chi^{(3)}$ were calculated for chosen peak laser in- 

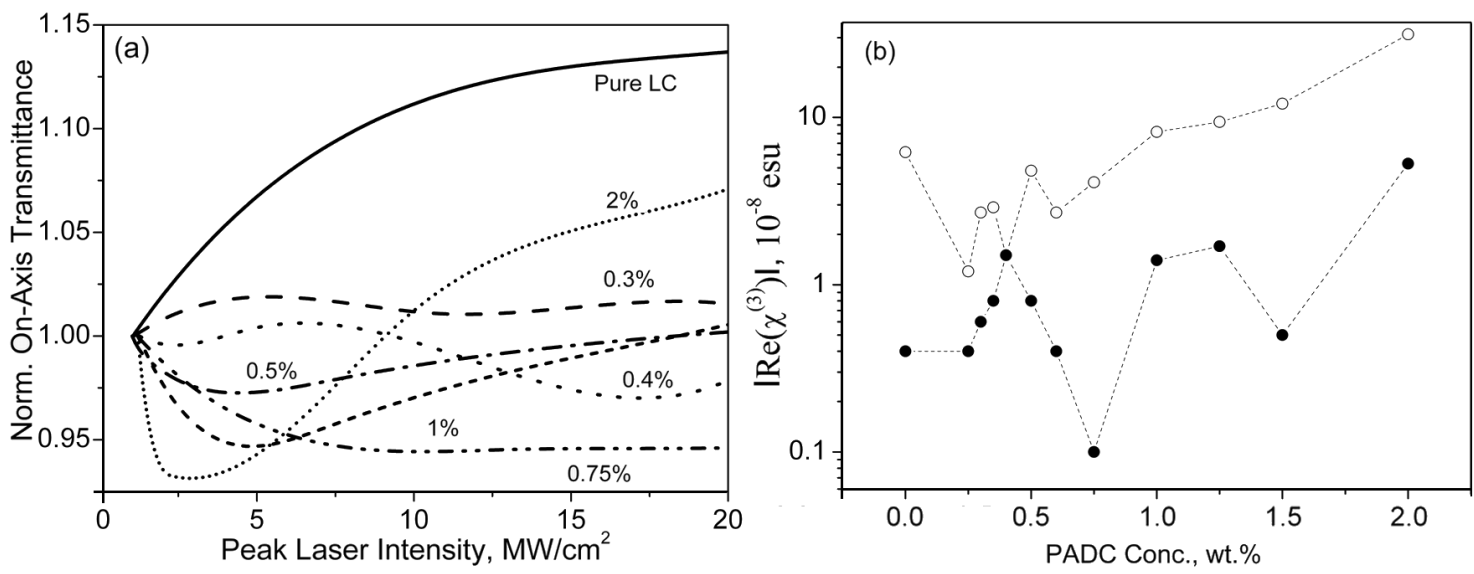

Fig. 4. The concentration dependences of: a) - the photoinduced on-axis transmittances variations of the PADC (wt.\%) doped LC cells versus the peak laser intensity at $532 \mathrm{~nm}$; b) - the real part of the cubic NLO susceptibility $\operatorname{Re}\left(\chi^{(3)}\right)$, circles correspond to the peak laser intensity $<3 \mathrm{MW} / \mathrm{cm}^{2}$, black dots - to the $5-20 \mathrm{MW} / \mathrm{cm}^{2}$.

tensity ranges A: $I<3 \mathrm{MW} / \mathrm{cm}^{2}$, B: $20<I<$ $50 \mathrm{MW} / \mathrm{cm}^{2}$, C: $50<I<200 \mathrm{MW} / \mathrm{cm}^{2}$ and D: $300<I<500 \mathrm{MW} / \mathrm{cm}^{2}$. The results are plotted as bar diagram and presented in Fig. 3. Transpared bars correspond to the $\operatorname{Re}\left(\chi^{(3)}\right)$ magnitudes, pattened - to the $\operatorname{Im}\left(\chi^{(3)}\right)$ correspondingly. It can be seen that for all samples the magnitudes decreases with the peak laser intensity rise.

In the case of the absorptive NLO response, the highest $\operatorname{Im} \chi\left({ }^{(3)}\right)$ was observed for the LC cell doped with PADC. We should note that for the range $D$ the $\operatorname{Im}\left(\chi^{(3)}\right)$ magnitudes coincide for the samples in the same matrix III-VI and IV-VII that points at the absence of the $\mathrm{AD}$ molecules bounding impact. We suggest that the fact is due to the possible turn away of $\mathrm{AD}$ molecules from polymer backbone at high peak laser intensities.

For the refractive NLO response, it can be seen that the highest $\operatorname{Re}\left(\chi^{(3)}\right)$ was observed for the samples with PADC (VI and VII).

Therefore, the presence of polymer and its bounding with AD is significant for NLO properties control despite polymer is not absorbing in the studied band. The NLO response enhancement due to polymer bonding with $\mathrm{AD}$ requires more thorough studies of LC doped with wide PADC concentrations range for more detailed interpretation of the obtained results.

Further, we present our studies of the refractive NLO response in a wide range of PADC concentration in LC.

2. The heterosystem refractive $N L O \quad r e-$ sponse versus $P A D C$ concentration
In order to analyze the impact of the PADC concentration on the heterosystems' photoinduced variations of the refractive index, the normalized on-axis transmittance dependences versus the peak laser intensity for the LC doped with $0.25-2$ wt.\% PADC concentration range were studied. The selected dependences are presented in Fig. 4a.

It can be seen that the PADC admixture leads to the reduction of the pronounced self-focusing effect efficiency observed for the pure LC matrix (see Sec. 3.1). The almost total compensation of the pure LC refractive NLO response at 0.3 wt. $\%$ PADC was observed. Further PADC concentration rise leads to the manifestation of self-defocusing effect at peak laser intensity $<5 \mathrm{MW} / \mathrm{cm}^{2}$ that turns to self-focusing. It can be seen that the efficiency of the processes is not proportional to the PADC concentration.

The magnitudes of the real part of the cubic NLO susceptibility $\operatorname{Re}\left(\chi^{(3)}\right)$ calculated for two peak laser intensity ranges $<3 \mathrm{MW} / \mathrm{cm}^{2}$ and $5-20 \mathrm{MW} / \mathrm{cm}^{2}$ are presented in Fig. 4b. The peculiarities in dependences at the PADC concentration about $0.4-0.5$ wt. $\%$ and 1-1.25 wt. $\%$ can be seen. The observed maxima/minima of the refractive NLO response efficiency at pronounced concentrations indicate three mechanisms with dominant contribution at corresponding PADC concentration range.

\section{Discussion}

In this work the following peculiarities for the heterosystem based on nematic LC with PADC were observed: 
i) higher refractive NLO response efficiency of the PADC doped LC versus the components response and conventional $\mathrm{AD}$ doped LC at different excitation level;

ii) the NLO response of the PADC-doped LC cannot be presented as a sum of the active components;

iii) different sign of the refractive NLO response of the PADC-doped and AD-doped LC;

iv) sign inversion of the PADC doped LC NLO response with the peak laser intensity rise;

v) the manifestation of three photoinduced mechanisms with the PADC concentration rise in LC matrix.

i) It should be stated that the most efficient (about $18 \%$ ) photoinduced on-axis transmittance variations were obtained for the PADC-doped LC. To our opinion, this enhancement is determined by the AD molecules bounding with the polymer backbone. The unbound $\mathrm{AD}$ molecules are embedded into LC matrix and surrounded with LC molecules all around. In the case of $\mathrm{H}$-bonded $\mathrm{AD}$ to the polymer side fragments, they are only partially encircled by LC molecules. As it was shown [4], the admixture of the PADC to LC matrix leads to the mesophase stabilization and order parameter increase of the LC. For the case of unbound $\mathrm{AD}$ molecules (same specific dye concentration) the effect was not observed. Thus, before the irradiation the cells were not in the same state that is the reason of their NLO response difference.

ii) It was observed that curve VII (Fig. 2) cannot be given as the sum of the curves $\mathrm{V}$ and VI or II, IV and V. It indicates that the NLO response of the PADC-doped LC cannot be reconstructed from the components NLO responses. In order to confirm that the heterosystem NLO response can not be presented as a sum of its components response we used the Effective Media Approximation (EMA) [15]. According to the EMA the AD/PADC partial contribution to the $\chi^{(3)}$ of the heterosystem were considered.

First, it was shown that in the LC matrix the partial contribution of the PADC subsystem is more efficient: $\chi^{(3)}$ PADC $=-$ $3.4 \cdot 10^{-7}$ esu, $\chi^{(3)} \mathrm{AD}=-2.5 \cdot 10^{-7}$ esu.

Second, we calculated the partial NLO responses of the PADC, AD and P4VP for the reference DMF solutions: $\chi^{(3)}{ }_{\mathrm{PADC}}=-1.0 \cdot 10^{-8} \mathrm{esu}$, $\chi^{(3)}{ }_{\mathrm{AD}}=1.7 \cdot 10^{-7} \mathrm{esu}, \chi^{(3)}{ }_{\mathrm{P} 4 \mathrm{VP}}=6.6 \cdot 10^{-9} \mathrm{esu}$. It can be stated that $\chi^{(3)} \mathrm{PADC} \neq \chi^{(3)} \mathrm{AD}+\chi^{(3)} \mathrm{P} 4 \mathrm{VP}$ and $\chi^{(3)}{ }_{\mathrm{PADC}+\mathrm{LC}} \neq \chi^{(3)}{ }_{\mathrm{LC}}+\chi^{(3)}{ }_{\mathrm{PADC}}$.
We think that these facts indicate that PADC acts as a single unit and when incorporated in LC creates new material with new properties.

iii) The different sign of NLO response of PADC- and AD-doped LC is determined by the same reason mentioned in (i): different structural arrangement of the unbounded and $\mathrm{H}$-bonded $\mathrm{AD}$ molecules in the matrix. Also the size and weight of the $\mathrm{AD}$ and PADC matters: PADC has 5 times more AD molecules plus polymer, which makes this unit less mobile. When irradiated the AD molecules undergo trans-cis isomerization with following re-orientation perpendicular to the light polarization [8]. In a case of AD-doped LC, AD molecules can easily reorient from initially homeotropicallyaligned state to planar one, becoming perpendicular to the light polarization. The photoinduced birefringence increases and self-focusing is observed. In a case of PADC, H-bonded AD also try to reorient perpendicular to the light electric vector, but PADC is more difficult to reorient and more energy is needed compared to the reorientation of unbound AD. since now much heavier unit needed to be re-oriented, it's easier for $\mathrm{AD}$ molecules to stay even better homeotropically-aligned (the improvement of homeotropic alignment). Thus $\Delta n$ is negative and self-defocusing is observed that is the different sign of NLO response compared to AD-doped LC.

iv) As it was noted, the refractive NLO response dependences on the peak laser intensity are not trivial: the sign and the magnitude significantly depend on the peak laser intensity. At low intensities, there is a self-defocusing in PADC-doped LC that is photoinduced birefringence decreases by aligning $\mathrm{H}$-bonded $\mathrm{AD}$ molecules in perpendicular to the light vector direction improving LC homeotropic alignment. At high intensities, there is a self-focusing determined by increasing of photoinduced birefringence. It can be caused either by reorientation of the PADC perpendicular to the light polarization vector in planar direction; or by decrease of the order parameter due to trans-cis isomerization and following enrichment with cis-forms of AD molecules; or by photogeneration of "free" $\mathrm{AD}$ molecules due to the break of the hydrogen bonds by intense laser radiation. $\mathrm{H}$-bonds breaking is a fast process with characteristic time less than 2 ps [16] that is much shorter than the laser pulses. The indirect proof of the effect is the coincidence of the NLO refractive re- 
sponse signs for the AD/PADC doped LC cells at higher peak laser intensities $>50 \mathrm{MW} / \mathrm{cm}^{2}$.

v) The next peculiarity is due to the PADC concentration impact. In general, the following processes can govern the photoinduced NLO response in PADC doped LC:

- photoinduced trans-cis/cis-trans transformation of the $\mathrm{AD}$; PADC;

- photoinduced orientation of the

- photogeneration of "free" AD molecules.

For the concentration range $\leq 0.5 \mathrm{wt} . \%$ the reorientation of the PADC dominates. The process leads to the LCs order parameter rise and consequent reduction of the self-focusing effect observed for the pure LC.

The photoinduced trans-cis transformation of the $\mathrm{AD}$ dominates for the PADC concentration range $0.5-1 \mathrm{wt} . \%$. The effect causes the positive photoinduced variations of the refractive index due to the LCs order parameter decrease [6]. The dominant contribution of the process leads to the reduction of the self-defocusing effect for the peak laser intensity range $<3 \mathrm{MW} / \mathrm{cm}^{2}$ and to the self-focusing effect enhancement for the range 5-20 MW/ $\mathrm{cm}^{2}$ (Fig. $4 \mathrm{~b}$ ).

For the concentration range $1-2$ wt. $\%$ the aggregation phenomenon causes the significant enhancement of the NLO response [17].

The observed results indicate the proposed PADC doped LC promising for nonlinear optics and photonics application

\section{Conclusions}

The NLO response studies of the heterogeneous system based on the nematic liquid crystal matrix with polymer-azo-dye complex were performed under picosecond range laser pulses excitation at $532 \mathrm{~nm}$. The higher efficiency of the heterosystem NLO response versus the components response and conventional AD doped LC was shown. The concentration dependences of the PADC doped LC refractive NLO response showed three ranges with different NLO properties. The phenomenon was attributed to the dominant contribution of the definite photoinduced mechanism: orientation of the PADC, trans-cis-trans isomerization and co- operative response/aggregation effect. The obtained results indicate the studied heterosystem promising for application in photonics due to the proper control of its NLO response with variation of $\mathrm{PADC}$ concentration.

Acknowledgement. Authors acknowledge V.Multian for the assistance in experiments, D.Lysenko and N.Sheremet for the samples' preparation. The work was partially supported by NASU V-166 and VC157 grants.

\section{References}

1. E.Ouskova, O.Buchnev, V.Reshetnyak et al., Liq. Cryst., 30, 1235 (2003).

2. E.Ouskova, O.Buluy, C.Blanc et al., Mol. Cryst. Liq. Cryst., 525, 104 (2010).

3. E.Ouskova, D.Lysenko, S.Ksondzyk et al., Mol. Cryst. Liq. Cryst., 545, 123/[1347] (2011).

4. E.Ouskova, J.Vapaavuori, M.Kaivola, Opt. Mater. Exp., 1, 1463 (2011).

5. E.Ouskova, M.Kaivola, Opt.Mater. Exp., 2, 1056 (2012).

6. A.V.Uklein, A.A.Vasko, E.V.Ouskova et al., Opt.Commun., 296, 79 (2013).

7. E.Ouskova, A.Pshenychnyi, A.Sanchez-Ferrer et al., JOSA B, 31, 1456 (2014)

8. I.A.Budagovsky, A.S.Zolot'ko, V.N.Ochkin et al., Zh. Eksper. Teor. Theor. Fiz., 106, 172 (2008).

9. E.A.Babayan, I.A.Budagovsky, S.A.Shvetsov et al., Phys. Rev. E, 82, 061705 (2010).

10. I.A.Budagovsky, V.N.Ochkin, M.P.Smayev et al., Liq. Cryst., 36, 101 (2009).

11. V.Ya.Gayvoronsky, L.A.Golovan, M.A.Kopylovsky et al., Quant.Electron., 41, 257 (2011).

12. V.Ya.Gayvoronsky, M.A.Kopylovsky, M.S.Brodyn et al., Laser Phys. Lett., 10, 035401 (2013).

13. V.Ya.Gayvoronsky, M.A.Kopylovsky, M.S.Brodyn et al., in: Nanomaterials Imaging Techniques, Surface Studies, and Applications, Edition: Springer Proceedings in Physics 146, New York, USA (2013), p.349.

14. V.Gayvoronsky, V.Timoshenko, M.Brodyn et al., Phys.Stat. Solidi (c), 2, 3303 (2005).

15. N.L.Dmitruk, A.V.Goncharenko, E.F.Venger, Optics of Small Particles and Composite Media, Naukova Dumka, Kyiv (2009).

16. V.Ya.Gayvoronsky, A.V.Uklein, A.O.Gerasov et al., J.Mol.Struct., 1045, 191 (2013).

17. V.Ya.Gayvoronsky, S.Yakunin, V.Nazarenko et al., Mol. Cryst. Liq. Cryst., 426, 231 (2005). 